Prethodno priopćenje UDK: 123(045)

doi: $\underline{10.21464 / \mathrm{fi} 41101}$

Primljeno 15. 2. 2020.

\author{
Lino Veljak \\ Zagorska 22, HR-10000 Zagreb \\ lveljak@ffzg.hr
}

\title{
O povijesti pojma slobode
}

\begin{abstract}
Sažetak
Pojam slobode (grč. eleuthería, lat. libertas) oblikuje se u antičkoj filozofiji u značenju privilegija koji pripada punoljetnim slobodnim građanima pa su mogućnosti slobode lišeni stranci, maloljetnici, žene i robovi. Takvu odredbu slobode preuzima i rimsko pravo, za razliku od stoičke filozofije i novozavjetnog kršćanstva, gdje se sloboda proširuje na sva ljudska bića. Dok stoici (bar djelomice) osuđuju ropstvo, dotle kršćanstvo eshatologizira slobodu (svi su ljudi slobodni kao Božja djeca, ali to ne implicira ukidanje ovozemaljskog ropstva). Srednji vijek nadovezuje se na takvo poimanje slobode, ali se u tom razdoblju uz ostalo formulira i sekularan pojam slobode, kakav posebice dolazi do izražaja u Magna carta libertatum. Moderni pojam slobode oblikuje se u novovjekovlju, od Lockeove odredbe života, slobode i vlasništva kao neotuđivih građanskih prava, preko Voltaireova zahtjeva za slobodom mišljenja i Rousseauova izjednačavanja slobode s ljudskom biti, pa do Kantova poimanja slobode koja je moguća samo posredstvom uma. Ideali Francuske revolucije sloboda, jednakost, bratstvo (liberté, égalité, fraternité) konkretiziraju se u Deklaraciji o ljudskim i građanskim pravima (a na granice tom deklaracijom postavljene slobode ukazat će Marx). Klasičnu liberalnu koncepciju slobode formulirat će pak John Stuart Mill, a danas se rasprave o slobodi vode, s jedne strane, na razini pitanja o individualnoj slobodi (primjerice, po Sartreovu i Camusovu mišljenju čovjek je nužno slobodan, dok je po nekim zastupnicima sociobiologije i istraživačima u polju neurobiologije ljudsko biće bitno genski determinirano), a s druge strane, na razini problematiziranja društvenih pretpostavki slobode ljudskog bića (gdje se u središtu diskusije nalazi pitanje je li privatno vlasništvo uvjet mogućnosti slobode ili je ono prepreka zbiljskoj slobodi).
\end{abstract}

\section{Ključne riječi}

sloboda, eshatologija, sekularnost, građanska prava, ljudska prava, um, jednakost, bratstvo, liberalnost, vlasništvo

\section{Uvod}

Riječ sloboda obuhvaća nekoliko različitih, uglavnom međusobno srodnih (premda ponekad i konkurentnih, a rjeđe i disparatnih) pojmova i ideja. Poput svih drugih pojmova i ideja ni ideje slobode nisu 'pale s neba' (iako bi neki rado da je bar jedna od njih upravo takvog postanja), nego nam one dolaze iz povijesti, čineći rezultat procesa njihove tvorbe. Hoćemo li rekonstruirati genezu pojma slobode (govorit ćemo zasad u jednini, ne gubeći iz vida njezinu naznačenu višeznačnost), suočit ćemo se s pluralnim karakterom njezina oblikovanja: poput značajnog dijela ključnih pojmova i ideja koji obilježavaju naše vrijeme i sloboda se oblikovala posredstvom dvojakosti našega svijeta ideja, u kojemu je sadržana, s jedne strane, povijesno posredovana baština grčko-rimskog svijeta, s druge strane, judeokršćanska baština, te s treće strane - ključne - sinteza antičke i židovsko-kršćanske tradicije izvedena primarno u kasnoj antici.

Sloboda je suprotnost nužnosti. ${ }^{1}$ Ukoliko bi, naime, svijetom vladao determinizam, utoliko bi bilo kakva rasprava o slobodi bila iluzorna. 
$\mathrm{Na}$ temelju opovrgavanja determinizma (bar opovrgavanja radikalnih verzija determinizma), profilirat će se dvije najznačajnije dimenzije pojma slobode: sloboda u smislu slobodne volje (engl. freedom) te sloboda u smislu političke slobode (engl. liberty), ${ }^{2}$ prvenstveno slobode individue u zajednici, ali sekundarno i u smislu slobodne zajednice (kolonija nije slobodna zajednica). Slobodna volja predstavlja temeljnu pretpostavku političke slobode i općenito slobode individue. Ova druga dimenzija bit će u središtu ovoga razmatranja.

\section{Grčko-rimska geneza pojma}

Hegel će u svojim znamenitim Predavanjima iz filozofije svjetske povijesti naglasiti kako se grčko-rimski svijet razlikuje od orijentalne despocije, u kojoj je slobodan samo jedan (dakle, slobodan je tek despot, apsolutni vladar), time što su zahvaljujući napretku svijesti o slobodi u tom svijetu slobodni $n e k i{ }^{3}{ }^{\mathrm{U}}$ grčkom su polisu doista slobodni neki: to su odrasli muškarci koji nisu ni stranci (stranci su potencijalno slobodni utoliko što neki među njima pod određenim okolnostima mogu steći zavičajnost), ni robovi (i oni su potencijalno slobodni, bar oni među robovima koji nemaju ropsku narav, a taj potencijal mogu aktualizirati ako ih njihovi vlasnici oslobode ropskog statusa); muška djeca također su potencijalno slobodna, a svoju potencijalnost automatski aktualiziraju stjecanjem punoljetnosti. Žene nisu slobodne niti to mogu postati jer je u njihovu narav upisana nesloboda (među Grcima u tom pogledu vlada opća suglasnost; iznimku čini tek Platon, koji otvara nekim ženama mogućnost da se uvrste među filozofe-vladare). Slobodnim građanima pripada eleutheria ${ }^{4}$ skup privilegija svojstvenih punoljetnim građanima polisa, koje se mogu svesti na pravo da bez prisile biraju različite mogućnosti što im stoje na raspolaganju te da donose odluke koje će od tih mogućnosti odabrati. ${ }^{5}$ Eksterna i interna sloboda polisa omogućuje slobodnim građanima kako participaciju u upravljanju javnim poslovima, tako i individualnu slobodu. Gorgijin učenik Alkidamas to najpreciznije definira: »sloboda je mogućnost svakoga da živi kako to želi«. ${ }^{6}$

Utoliko je sloboda svojstvo slobodnih pojedinaca. No, sloboda je i političko stanje: Platon i Aristotel razlikuju pravu slobodu od bezvlašća (stanja slobode bez zakona) i od despocije (vladavine zakona bez slobode). Rimljani preuzimaju takav pojam slobode, čiji su dionici neki (tj. slobodni rimski građani), prevodeći ga kao libertas. ${ }^{7}$ Međutim, u helenističkom će razdoblju stoici (bar neki među njima) dovesti u pitanje smije li se sloboda ograničiti na neke ili bi ona trebala pripadati svim ljudskim bićima, te će neki stoici dovesti u pitanje i samu opravdanost ropstva. ${ }^{8} \mathrm{Tu}$ će ideju slobode koja pripada svim ljudskim bićima preuzeti kršćanstvo, utemeljujući je u transcendenciji i uvodeći je tako u eshatologijsku dimenziju.

\section{Stari Zavjet}

Kršćanstvo nije, dakako, rezultat razvijanja stoičke filozofije, iako se ne mogu osporiti neki (možda i bitni) utjecaji stoicizma na pojavu kršćanstva. Ono je, prije svega, učinak radikalne (upravo revolucionarne) reforme najstarijeg monoteizma, judaizma, i predstavlja svojevrstan diskontinuirani kontinuitet starozavjetne tradicije.

U starozavjetnim spisima pojam slobode prvenstveno se tematizira u kontekstu oslobođenja, ali ne individualnog oslobađanja i oslobođenja, već oslobo- 
đenja zajednice (u konkretnom slučaju: naroda Izraela) od ropstva, počevši od Mojsijem predvođenog oslobođenja židovskog naroda od egipatskog ropstva (Izl. 1,1-15,21) pa do oslobođenja Židova od babilonskog sužanjstva. Ne bi, ipak, trebalo zanemariti i dimenziju individualne slobode. U tom smislu, valja upozoriti na razliku između starozavjetnih hebrejskih pojmova rahav i deror. Rahav upućuje na stanje u kojemu nema prepreka da se čini ono što je dobro

1

Usp. Hana Arent [Hannah Arendt], Život duha, prev. Adriana Zaharijević, Aleksandra Bajazetov, Službeni glasnik - Alexandria Press, Beograd 2010., str. 80.

Po jednom popularnom tumačenju (koje se poziva na Viktora Frankla), freedom se odnosi na unutarnju slobodu, dok bi se liberty (pozivom na stoike te na značenje koje je taj termin zadobio u ustavu Sjedinjenih Država, u smislu slobode od represije i slobode izbora načina života, ponašanja i političkih stavova), odnosio na eksternu slobodu. Usp. Brian Miller, »Freedom vs. Liberty: How Subtle Differences Between These Two Big Ideas Changed Our World«, Ammo. Dostupno na: https:// ammo.com/articles/freedom-liberty-difference-understanding-negative-vs-positive-rights (pristupljeno 6. 7. 2019.). Po drugom popularnom tumačenju ta su dva termina sinonimi, s time što bi liberty bio subordinirani pojam, oblik onoga što se imenuje kao freedom. Prvi termin odnosio bi se na slobodu odlučivanja, a drugi na slobodu djelovanja. Usp. Emelda M, »Liberty vs Freedom«, $D i$ fferenceBetween. Dostupno na: http://www differencebetween.net/miscellaneous/politics/difference-between-liberty-and-freedom (pristupljeno 6. 7. 2019.). Na drugim jezicima to razlikovanje nije prisutno pa se tako na njemačkom koristi pojam Freiheit $\mathrm{u}$ oba engleska značenja, a zanimljivo je da se popularno objašnjenje razlike podudara s prethodno navedenim tumačenjem: Freedom bi bio univerzalan pojam, dok bi se liberty odnosio na specijalne političke, vjerske, građanske i sl. slobode, te na izbor određenog ponašanja ili čina. Usp. https://www.duden.de/ rechtschreibung/Freiheit; https:/www.stern. de/noch-fragen/was-ist-der-unterschied-zwischen-liberty-und-freedom-3000018329.html (pristupljeno 6. 7. 2019.)

Po Hegelu, razlika između svijesti o slobodi svojstvene istočnom svijetu i one grčkom i rimskom svijetu jest ta da je po istočnjacima slobodan samo jedan, dok su za Grke i Rimljane slobodni neki. Usp. Georg Wilhelm Friedrich Hegel, Vorlesungen über die Philosophie der Weltgeschichte, F. Meiner Verlag, Hamburg 1966., str. 33.
Pojam je nastao u 5. st. p. n. e. u vrijeme grčko-perzijskih ratova, a prije toga je pridjev eleutheros (iz kojega je izveden pojam eleuthería) označavao odnos gospodara i roba (suprotan pojam doulos), kako to posebno dolazi do izražaja kod Solona. U apstraktnom se značenju slobode eleuthería ne koristi prije 479. godine p. n. e. Usp. Shane Wallace, The Freedom of the Greeks in the Early Hellenistic Period (337-262 $B C$ ), University of Edinburgh Press, Edinburgh 2011., str. 18-20.

Usp. Dieter Nestle, Eleutheria: Studien zum Wesen der Freiheit bei den Griechen und im Neuen Testament, Mohr, Tübingen 1967.

Prema: William Keith Chambers Guthrie, The Sophists, Cambridge University Press, Cambridge 1977., str. 159-160.

No, s rimskim osvajanjem Grčke faktičko se stanje slobode bitno mijenja u odnosu na stanje kakvo je vladalo u predaleksandrovskom demokratskom polisu, o čemu izvještava Plutarh u Životu Tita Flaminija (usp. Plutarch, »The Life of Titus Flamininus«, u: Plutarch, The Parallel Lives. Dostupno na: http://penelope.uchicago.edu/Thayer/E/Roman/Texts/ Plutarch/Lives/Flamininus*.html (pristupljeno 26. 6. 2019.); prema: Plutarch, Lives, sv. 10, Agis and Cleomenes, and Tiberius and Caius Gracchus, Philopoemen and Titus Flaminius, prev. Bernadotte Perrin, Harvard University Press - William Heinemann, Cambridge (MA) - London 1921. Sloboda se sada odnosi samo na Rimljane, a indikativno je da Tacit pojam libertas brka s pojmom licentia: sloboda se tako izjednačava s ovlašću ili čak s dozvolom. Usp. Chaim Wirszubski, Libertas as Political Idea at Rome during the Late Republic and Early Principate, Cambridge University Press, Cambridge 1950., str. 7, posebno str. $142 \mathrm{i}$ d).

To posebice važi za Hrizipa, drugog utemeljitelja stoicizma. Usp. Josiah Gould, The Philosophy of Chrysippus, SUNY Press, New York 1970., posebno str. 163. O toj problematici usp. i Susanne Bobzien, Determinism and Freedom in Stoic Philosophy, Oxford University Press, Oxford 1998. 
i pravedno (Ps. 119,45), dok deror predstavlja suprotnost ropstvu (doslovno: okovima), te se primjenjuje na robove koji su oslobođeni svog ropskog statusa (3. Ms. 25,10; Is. 61,1). Individualna sloboda profilira se kao posjedovanje širine (širokog pojasa djelovanja) što omogućuje podvrgavanje Jahveovim zapovijedima (ili je pak rezultat ustrajnosti u pridržavanju tih zapovijedi), kao što to formulira Psalam 119: »I hodit ću na prostoru širokom, jer sam nastojao oko propisa tvojih.«

U starozavjetnim spisima, kao što je rečeno, izrazit se primat pridaje slobodi zajednice, izabranog naroda Izraela: Jahve daje svom izabranom narodu slobodu izbavljujući ga od egipatskog ropstva (Izl. 20,2), a oduzima mu je uslijed njegove neposlušnosti, dopuštajući asirska i babilonska osvajanja njegovih kraljevstava i potonje sužanjstvo (2. Kr. 17,7-23 i 2. Kr. 21,10-27). Sloboda je, dakle, Jahveov dar izabranom narodu, koji darodavac može oduzeti ako ga narod ne zaslužuje, ali i iznova vratiti zahvaljujući njegovu milosrđu. ${ }^{9}$

\section{Novozavjetno razumijevanje slobode}

Novozavjetno razumijevanje slobode u potpunosti se usredotočuje na slobodu individue. Pojam eleuthería u prvom se redu odnosi na slobodu od grijeha i od smrti (što je uvijek vezano uz pojedinca - individue griješe i umiru, a zajednica griješi i umire isključivo posredstvom grijeha i umiranja njezinih pripadnika, individualnih osoba), ali i na karakter individualne slobode, uvijek kao sloboda za druge. Konačno, Novi Zavjet problematizira i pitanje slobode u socijalno-statusnoj dimenziji, odnos slobodnih ljudi i robova, dapače, odnos gospodara i roba (ne, razumije se, u hegelovskom smislu riječi). ${ }^{10}$

Po instruktivnom tumačenju njemačko-američkog teologa Hansa Dietera Betza, pojam slobode ima jednu od ključnih uloga u nauku o spasenju apostola Pavla. U njegovo je vrijeme klasični grčki pojam slobode u velikoj mjeri bio sveden na jedan stari san. Ni u Rimu ni u Grčkoj i drugim provincijama Imperija nije bilo političkih i socijalnih struktura koje bi dopuštale oživotvorenje onoga što je klasični grčki pojam obećavao, tako da se izvorno politički pojam pretvorio u jedan apolitičan ili čak i antipolitički pojam. ${ }^{11}$

No, sloboda je bitan pojam već i u evanđeljima, gdje je ona usko povezana s oslobođenjem i spasenjem. Spasitelj Isus Krist osloboditelj je i iskupitelj: »Ako vas Sin oslobodi, doista ćete biti slobodni« (Iv. 8,36). I dalje: »Ako ustrajete u mojoj nauci, uistinu ste moji učenici, upoznat ćete istinu, a istina će vas osloboditi« (Iv. 8,31-32). Oslobođenje o kojemu je tu riječ duhovne je naravi, to je oslobođenje od grijeha, te time i od vječne smrti, a politička bi sloboda u ovom sklopu bila bez ikakva značenja: »Dajte caru carevo, a Bogu Božje« (Mt. 22,21-22, Mk. 12,17, Lk. 20,26). Ne treba, međutim, zanemariti da se starozavjetno naglašavanje socijalno-političke dimenzije oslobođenja danas, posebice u okviru teologije oslobođenja, izravno prenosi ili primjenjuje na tumačenje smisla i značenja novozavjetne objave te se $u$ tom smislu u mjerodavnom talijanskom leksikonu teologije može pročitati kako »oslobođenje siromašnih i potlačenih predstavlja središnji moment mesijanskog spasenja i ono označava budućnost koju Bog namjerava i obećava, jednako kao što označava i smjer njegovih sadašnjih zahvata. $\ll^{12}$

U poslanicama apostola Pavla sloboda zauzima istaknuto mjesto - moglo bi se reći čak i središnje. ${ }^{13} \mathrm{U}$ tom smislu, od bitne je važnosti poslanica Galaćanima, u kojoj čitamo: »Za slobodu vas Krist oslobodi. Budite dakle postojani i ne dajte se ponovno u jaram ropstva $($ Gal. 5,1$) .{ }^{14}$ Eleuthería je ovdje sloboda 
od grijeha, koji vodi u ropstvo i propadljivost. A svrha te slobode sastoji se u služenju zajednici zasnovanom na ljubavi: »Vi ste braćo, doista, pozvani na slobodu. Samo ne na slobodu za izliku tijelu nego - ljubavlju služite jedni drugima.«(Gal. 5,13). Ključnim bi se mjestom Pavlovih razmatranja o slobodi mogla ispostaviti radikalizacija stoičkih slutnji o principijelnoj jednakosti svih ljudskih bića koja dolazi do izražaja u stavu »Nije više važno je li tko židov ili poganin, rob ili slobodan čovjek, pa čak ni muškarac ili žena - jer svi ste jedno u Kristu Isusu« (Gal. 3,28). Valja, međutim, zapaziti da je ovdje riječ o jedinstvu, a ne o jednakosti (osim jednakosti u dimenziji transcendencije, koja se odnosi ‘čak' i na žene), pa se utoliko smije govoriti isključivo o duhovnoj slobodi, a ne i o faktičkoj slobodi: robovi ostaju robovima, a žene ne gube svoju inferiornu (kako bi neki rekli: drugotnu) narav. Da se jednakost ne proširuje i na ovozemaljsku dimenziju rječito svjedoče Pavlove napomene, poput »Robovi neka se svojim gospodarima u svemu podlažu, ugađaju im, ne proturječe, ne pronevjeruju, nego neka im iskazuju svaku dobru vjernost, da u svemu budu ures nauku Spasitelja našega, Boga« (Titu. 2,9-10), te »Robovi, slušajte svoje zemaljske gospodare kao Krista - sa strahom i trepetom, u jednostavnosti srca« (Ef. 6,5). Robovlasnike, pak, Pavao poziva na blagost u postupanju s robovima: »Gospodari, pružajte svojim robovima što je pravo i pravično, znajući da i vi imate Gospodina na nebu.« (Kol. 4,1). A što se tiče žena, tu je Pavao jasan: »Neka žene vaše u crkvama šute« (1. Kor. 14,34).

Transcendentna dimenzija jednakosti svih ljudskih bića ne implicira, dakle, ni ovozemaljsku slobodu robova (koji ostaju u ropskom statusu), ni jednakost muškaraca i žena. Ipak, načelna mogućnost dana svim ljudskim bićima za slobodu od grijeha i smrti, zasnovana na njihovu statusu Božje djece, otvorit će prostor za prijelaz iz stanja slobode nekih u stanje slobode svih. To će novo

O bitnim dimenzijama starozavjetnog razumijevanja slobode usp. Reinhard Achenbach, Ruth Ebach, Jakob Wohrle (ur.), Wege der Freiheit. Zur Entstehung und Theologie des Exodusbuchs, Theeologischer Verlag, Zürich 2014. Usp. također i (kvalitetan, premda u pogledu Starog Zavjeta tematski ograničen na pitanje slobode kulta) članak Ivice Čatića »Vjerska sloboda u Bibliji«, Diacovensia 21 (2013) 4, str. 599-608.

10

Usp. Kurt Niederwimmer, Der Begriff der Freiheit im Neuen Testament, Töpelmann, Berlin 1966.

11

Usp. Hans Dieter Betz, Paulinische Studien, Mohr, Tűbingen 1994. Posebno je značajno šesto poglavlje pod naslovom »Paul's Concept of Freedom in the Context of Hellenistic Discussions about Possibilities of Human Freedom«, str. 110-125 (objavljeno na engleskom jeziku, a prema informaciji izdavača postoji i njemačka varijanta Betzovih sabranih djela). Zanimljivo je, također, i Badiouovo tumačenje Pavla kao pomiritelja univerzalnosti i partikularnosti, on afirmira slobodu od pokoravanja starozavjetnom zakonu (usp. Alain Badiou, Sveti Pavao: utemeljenje univerzalizma, prev. Marko Gregorić, Naklada Ljevak, Zagreb 2006.).

12

Giuseppe Gatti, »Liberazione«, u: Luciano Pacomio (ur.), Dizionario teológico interdisciplinare, sv. II, Marietti, Torino 1977., str. 385 .

13

Usp. Hyam MacCoby, The Mythmaker: Paul and the Invention of Christianity, HarperCollins, New York 1987.; Rinaldo Fabris, Paolo. L'apostolo delle genti, Paoline Editoriale Libri, Milano 1997.; Alfred Suhl, Die Briefe des Paulus: eine Einführung, Katholisches Bibelwerk, Stuttgart 2007.; Thomas Schmeller, Der zweite Brief an die Korinther, Patmos-Verlag, Düsseldorf 2010

14

Sloboda u Poslanici Rimljanima dobiva čak i transhumanu, upravo kozmičku dimenziju: „Sve što je na Zemlji stvoreno postalo je jalovim, ne vlastitom nego Božjom voljom ali u nadi da će biti oslobođeno od robovanja pokvarljivosti, da sudjeluje u slobodi i slavi Božje djece« (Rim. 8,20-21). Usp. Samuel Vollenweider, Freiheit als neue Schöpfung, Vandenhoeck \& Ruprecht, Göttingen 1989. 
stanje Hegel tematizirati pod imenom »kršćansko-germanske svijesti duha o slobodi«, koje se u ovozemaljskoj povijesti po prvi puta obistinjuje među germanskim plemenima. ${ }^{15}$

\section{Srednji vijek}

Naznačeno poimanje slobode $\mathrm{s}$ izrazitim primatom njezine transcendentne dimenzije dominira i u europskom srednjovjekovlju. No, pozornost zaslužuje jedan zanimljivi novum. Još u 11. stoljeću njemački augustinac Manegold von Lautenbach formulirao je pravo naroda na pobunu protiv tiranstva (a to pravo uključuje i legitimnost tiranicida). ${ }^{16}$ Potom će Anglosaksonac, skolastički filozof i crkveni diplomat Ivan od Salisburyja oko 1159. godine objaviti spis pod naslovom Policraticus, sive de nugis curalium et de vestigiis philosophorum, poznatiji pod imenom Metalogicon.${ }^{17}$ Raspravljajući o božanskom legitimitetu kraljevske vlasti, on u tom spisu uvodi razlikovanje vladara od tiranina te afirmira pravo naroda na tiranicid. Takvo poimanje prava na svrgavanje i ubojstvo tiranina preuzet će i Toma Akvinski, koji inače slobodu definira kao vladavinu volje nad vlastitim djelom, intelektom i drugim moćima te općenito nad svim posebnim dobrima, što se zasniva na slobodi volje koju ljudi posjeduju utoliko što su racionalna bića. ${ }^{18}$

Izuzmemo li pravo na tiranicid (a ovaj postaje prihvatljivim tek kad se suveren preobrazi u tiranina), srednjovjekovlje ograničava političku slobodu na dužnost pokoravanja božanski legitimiranom vladaru. Ipak, upravo se u tom razdoblju iznova otvara sekularno značenje političke i individualne slobode. U tom smislu od ključne je važnosti engleska Magna carta libertatum (1215.). ${ }^{19}$ Sekularna dimenzija slobode tu dolazi do jasnog izražaja.

U nastojanju da uspostavi mir između nepopularnog kralja Ivana Bez Zemlje i pobunjenog plemstva, nadbiskup Canterburyja Stephen Langton izradio je prvi nacrt te povelje, kojom se, s jedne strane, jamče stanovita crkvena prava te ograničavaju kraljevska prava, a s druge strane, jamče određena prava $\mathrm{i}$ slobode plemstvu i svim slobodnim ljudima (primjerice, zabrana samovoljnog lišavanja slobode). Po ocjeni Toma Denninga, ta je povelja »najvažniji konstitutivni dokument svih vremena: utemeljenje slobode individue nasuprot proizvoljna despotskog autoriteta ${ }^{20}{ }^{20}$ Time se profilira onaj - ekskluzivno sekularan - pojam slobode koji će u bitnoj mjeri obilježiti novovjekovlje.

\section{Moderni pojam slobode}

Na tragu Magna carte, oblikuju se u prvom redu britanske koncepcije slobode. Na početku novovjekovlja na nju će se pozivati Francis Bacon, ${ }^{21}$ a na toj je crti i utemeljitelj liberalne političke teorije John Locke koji formulira vjerojatno najutjecajniju modernu koncepciju slobode. Nasuprot Hobbesu, koji slobodu zasnovanu na poštivanju zakona pripisuje isključivo Levijatanu (suverenu ili državi), a podanicima pripisuje dužnost pokoravanja vlastima (u zamjenu za sigurnost koju im one jamče), ${ }^{22}$ Locke ne samo što reafirmira pravo naroda na pobunu protiv tiranije nego i oblikuje cjelovitu koncepciju vladavine prava, moderne liberalne i demokratske države, obilježene dominacijom slobode i autonomije pojedinca, pri čemu su život, jednakost (uključujući i jednakost muškaraca i žena), ${ }^{23}$ sloboda i vlasništvo definirani kao neotuđiva građanska prava. Sloboda je za njega stanje u kojemu pojedinac u okviru granica prirodnog zakona odlučuje o svojim djelima te raspolaže svojim imet- 
kom i vlastitom osobom bez da od ikoga za to traži odobrenje ili da ovisi o volji nekoga drugoga. ${ }^{24} \mathrm{Na}$ tom su tragu i razmišljanja Davida Humea, ali i - gotovo dva stoljeća kasnije - autora jedne od najutjecajnijih klasičnih koncepcija liberalizma Johna Stuarta Milla, koji je u svom znamenitom spisu $O$ slobodi uspostavio jasnu razliku između slobode činjenja (liberty) i slobode kao odsutnosti prinude (također liberty) ${ }^{25}$

Bitan doprinos oblikovanju modernog pojma slobode dalo je i francusko prosvjetiteljstvo. Reprezentativan je u tom pogledu Voltaire, koji će ideju slobode (identificiranu s htijenjem i djelovanjem) elaborirati u okviru svojega zalaganja za princip tolerancije, koji je prvi zakon prirode, temelj svih ljudskih

15

Usp. G. W. F. Hegel, Vorlesungen über die Philosophie der Weltgeschichte.

16

Usp. Johannes Laschinger, »Manegold von Lautenbach«, u: Neue Deutsche Biographie, sv. 16, »Maly - Melanchthon«, Duncker \& Humblot, Berlin 1990., str. 21-22.

17

Usp. John D. Hosler, John of Salisbury: Military Authority of the Twelfth-Century Renaissance, Brill, Leiden 2013.

18

Usp. Federica Bergamino, La razionalità e la libertà della scelta in Tommaso d'Aquino, Ed. Santa Croce, Rim 2002., str. 275-276.

19

Usp. Peter Linebaugh, The Magna Carta Manifesto. Liberties and Commons for All, University of California Press, Berkeley 2009.; Vincent Nicholas, Magna Carta: A Very Short Introduction, Oxford University Press, Oxford 2012.

\section{0}

Navedeno prema: Danny Danziger, John Gillingham, 1215: The Year of Magna Carta, Coronet, London 2004., str. 278.

21

Usp. William H. Dunham, »Magna Carta and British Constitutionalism«, u: Samuel E. Thorne et al., The Great Charter: Four Essays on Magna Carta and the History of Our Liberty, Pantheon Books, New York 1965., str. 20-42, posebno str. 34.

\section{2}

Usp. Thomas Hobbes, De cive. The Latin version entitled in the first edition Elementorum philosophiae sectio tertia de cive, and in later editions Elementa philosophica de cive, Clarendon Press, Oxford 1983., XIV, 1.

23

Slijedilo bi da je Locke sekularizirao Pavlovo uspostavljanje jednakosti muškaraca i žena. No, takav bi zaključak bio ishitren: dovoljno bi bilo uzeti u obzir kako je još koncem
Srednjeg vijeka Christine de Pizan u svom djelu Grad žena (1404. - 1405.) ponudila bogatu argumentaciju u prilog uspostavljanja ovozemaljske ravnopravnosti žena s muškarcima. Usp. Simone Roux, Christine de Pizan. Femme de tête, dame de cour, Payot \& Rivages, Pariz 2006. No, možemo ići i u dublju povijest ideja: ne možemo, nažalost, znati što je filozofkinja i matematičarka Hipatija, novoplatoničarka i upraviteljica Aleksandrijske knjižnice (a ako je ta ustanova predstavljala prvi moderni univerzitet po kriterijima Bologne i Humboldta - da je tomu uistinu tako dokazuje Zoran Dimić, usp. Rađanje ideje univerziteta, Izdavačka knjižarnica Zorana Stojanovića, Sremski Karlovci 2013. - onda zapravo: rektorica), mislila o sekularizaciji slobode i jednakosti muškaraca i žena jer su njezine spise uništili fanatični Pavlovi sljedbenici, ali znamo što je o tomu mislio Platon (u tom pogledu iznimka među antičkim filozofima), koji u Državi sposobnost pristupanja staležu filozofa-vladara pripisuje kako muškarcima tako i ženama.

24

»... stanje savršene slobode da upravljaju svojim postupcima, lišavaju se svojih posjedovina i osoba kako im odgovara, u granicama Zakona Prirode, bez da traže dopuštenje ili ovise o Volji bilo kojega drugoga čovjeka.« - John Locke, Two Treatises of Government: The Second Treatise of Government, Cambridge University Press, Cambridge 2012., II, $\S$ 4. O Lockeu usp. i: Richard Ashcraft, Revolutionary Politics \& Locke's Two Treatises of Government, Princeton University Press, Princeton 1986

25

Usp. John Stuart Mill, Izabrani politički spisi, sv. I, prev. Nadežda Čačinovič-Puhovski, Julije Knežević, Adam Krlić, Informator - Fakultet političkih nauka, Zagreb 1988. O Millu usp. Slaven Ravlić, Poredak slobode: politička misao Johna Stuarta Milla, Hrvatsko filozofsko društvo, Zagreb 2001.; Maurice Cranston, John Stuart Mill, Longmans, Green and Co., London 1967. 
prava i razlikovni moment čovjeka u odnosu na životinjsko stanje. ${ }^{26}$ Posebnu pozornost on pridaje slobodi mišljenja i izražavanja, koje za njega čine središnji moment ideje slobode. ${ }^{27}$

Ako je Voltaire reprezentativan za glavni smjer prosvjetiteljskog tematiziranja slobode, to nipošto ne implicira opravdanost zanemarivanja jednoga diferenciranog pristupa koji nalazimo u djelu Jean-Jacquesa Rousseaua. Poput svojih suvremenika prosvjetitelja, Rousseau ${ }^{28}$ zastupa stav po kojemu sloboda pripada biti ljudskoga bića te je utoliko ona karakteristična za prirodno stanje ljudi, ali njegov se pomak očituje u tomu što je u modernim okolnostima društva i civilizacije sloboda u značajnoj mjeri razorena. Sve su stvari stvorene dobre, ali ih mi sve kvarimo našim rukama, stoji na početku njegova Emila. ${ }^{29}$ Nasuprot Hobbesu, Rousseau dokazuje kako kompetitivnost $\mathrm{i}$ agresivnost ne pripadaju primitivnom čovjeku, već su one nastale povijesno i svoj postanak mogu zahvaliti uspostavljanju privatnog vlasništva ${ }^{30} \mathrm{U}$ prvobitnom stanju (obilježenom »izvornom neiskvarenošću«) vlada organsko jedinstvo mira, slobode i jednakosti, a razvitak ljudskih sposobnosti dovodi do nejednakosti i nasilja. Raspad onoga organskog jedinstva ograničava slobodu, koju Rousseau inače identificira sa samim životom:

»Odustajanje od vlastite slobode znači odustajanje od vlastite ljudskosti, od ljudskih prava, čak i od vlastitih dužnosti [...]. Takvo odustajanje nespojivo je s ljudskom prirodom; oduzeti čovjeku svaku slobodu znači i oduzimanje svake moralnosti njegovim djelima. $\aleph^{31}$

Više je nego zanimljivo i to što Rousseau uočava još jedno ograničenje slobode svojstveno modernim vremenima:

„Čovjek, nekoć slobodan i neovisan, porobljen je zahvaljujući velikoj količini novih potreba [...] prije svega od sebi sličnih, kojima u stanovitom smislu postaje robom, čak i kad im je gospodar. $\ll^{32}$

Ostavimo li po strani Rousseauovo - dakako, višestruko problematično - idealiziranje nekadašnjih »sretnih vremena« iskonskog stanja, moramo se zapitati nije li on ovdje (a citirani pasus nije jedini te vrste koji možemo sresti u njegovim spisima) anticipirao ono što će se koncem 20. stoljeća tematizirati pod imenom kritike novih oblika ropstva svojstvenih tzv. potrošačkom društvu.

Valja, konačno, spomenuti i Rousseauovo naglašavanje važnosti političke slobode, koja je moguća na temelju društvenog ugovora, čime se prirodna sloboda preobražava u građansku slobodu. Sloboda ostaje fundamentalnom vrednotom od koje se nikad ne smije odustajati jer je sloboda isto što i bit ljudskosti. ${ }^{33}$

\section{Negativna i pozitivna sloboda}

Rousseauova koncepcija slobode jasno se profilira kao pozitivna sloboda, dakle, sloboda za; time se ta koncepcija razlikuje od one koju zastupaju liberali (od Lockea do Milla, pa do - u našim danima - primjerice, Isaiaha Berlina), ${ }^{34}$ koja stavlja naglasak na uklanjanje prepreka slobodi pojedinca kao individue, formulirajući na taj način koncepciju negativne slobode, slobode od prepreka koje onemogućuju pojedincu da bira i odlučuje. ${ }^{35}$ Pozitivna sloboda često se identificira sa slobodom izbora zasnovanoj na slobodnoj volji, koju mnogi suvremeni Hobbesovi sljedbenici dovode u pitanje ili čak i jednoznačno osporavaju. ${ }^{36}$ 
Najznačajniji klasični zastupnik pozitivnog pojma slobode nedvojbeno je Immanuel Kant. Liberalna negativna koncepcija slobode (a Kant, jednako kao i Rousseau, uviđa prepreke slobodi koje valja ukloniti, iako oni ne vrše njihovu redukciju na onaj način koji je bio svojstven klasičnom liberalizmu, a koji danas osobito zastupaju tzv. neoliberali) ${ }^{37}$ nije dovoljna za konstituiranje političke zajednice. Kant definira slobodu kao neovisnost od kauzalnosti te je poima kao praktičku slobodu, tj. mogućnost umom obdarenog bića da djeluje neovisno o osjetilnim porivima. Iako se determinizam teorijski ne može pobiti pa se onda pitanje o slobodnoj volji na razini čistog uma ne može osloboditi svoje antinomičnosti, ${ }^{38}$ praktička se sloboda može empirijski dokazati te smo u stanju pomoću uma odlučiti što je korisno, a što pak štetno, što je dobro, a što zlo - i djelovati u skladu s time. Na taj način kroz djelovanje stječemo

26

Usp. Voltaire, Rasprava o toleranciji, prev. Bosiljka Brlečić, Matica hrvatska, Zagreb 1997. O Voltaireu usp. Roger Pearson, Voltaire Almighty: A Life in Pursuit of Freedom, Bloomsbury, London 2005.; Guy Chaussinand-Nogaret, Voltaire et le siècle des $\mathrm{Lu}$ mières, Éditions Complexe, Bruxelles 1994. $\mathrm{O}$ afirmaciji principa tolerancije u prosvjetiteljstvu usp. Ole Peter Grell, Roy Porter (ur.), Toleration in Enlightenment Europe, Cambridge University Press, Cambridge 2000.

27

Usp. Voltaire, Filozofijski rječnik, prev. Boris Lukić, Publikum, Zagreb 2004.

28

Rousseaua nerijetko svrstavaju među francuske moraliste; najnoviju klasifikaciju Rousseaua kao moralista daje litvanski filozof i kulturolog Antanas Andrijauskas, koji ga uvrštava u skupinu s Montaigneom i Pascalom. Usp. Antanas Andrijauskas, »Reflections on an Existential Crisis in Søren Kierkegaard's Aesthetic Conception «, Dialogue and Universalism 29 (2019) 2, str. 29-41, ovdje str. 35, doi: https://doi.org/10.5840/du201929219.

29

Usp. Žan-Žak Ruso [Jean-Jacques Rousseau], Emil ili $O$ vaspitanju, prev. Dušan Tamindžić, Estetika, Valjevo - Beograd 1989., str. 7.

30

Izvrsnu analizu Rousseauove koncepcije u okviru recentne literature nudi Guglielmo Forni Rosa. Usp. Guglielmo Forni Rosa, »Libertà naturale e libertà civile nell'opera di Jean-Jacques Rousseau«, u: Claudio Tagnoli (ur.), Libero arbitrio. Teorie e prassi della libertà, Liguori, Napulj 2014., str. 231-247.

31

Jean-Jacques Rousseau, Euvres complètes, sv. III, Gallimard, Pariz 1964., str. 356.

32

Ibid., str. 174-175.
33

Usp. G. Forni Rosa, »Libertà naturale e libertà civile nell'opera di Jean-Jacques Rousseau«, str. 241.

34

Instruktivno je u tom smislu Berlinovo djelo Four Essays on Liberty, Oxford University Press, Oxford 1982. O Berlinu usp. George Crowder, Isaiah Berlin: Liberty, Pluralism, and Liberalism, Polity Press, Cambridge 2004.

35

Pozitivna pretpostavka te slobode sastoji se od slobode poduzetništva i slobodnog tržišta, kako je to klasično elaborirao još Adam Smith. Usp. David F. Hardwick, Leslie Marsh (ur.), Propriety and Prosperity: New Studies on the Philosophy of Adam Smith, Palgrave Macmillan, London 2014., posebno priloge Kevina Kennedyja »The 'Invisible Hand' Phenomenon in Economics«, str. 198-222, te Lauren K. Hall, »Two Invisible Hands: Family, Markets, and the Adam Smith Problem«, str. 240-253.

36

Usp. pregled suvremenih rasprava usmjerenih na ograničavanje opravdanosti primjene pojma slobode isključivo na negativnu slobodu $\mathrm{u}$ : Guido Tonietto, La libertà in questione. Uno studio su e oltre Aristotele, Mimesis, Sesto San Giovanni 2008., str. 15 i d. 37

Usp. npr. Patrick Schreiner, Unterwerfung als Freiheit. Leben im Neoliberalismus, PapyRossa, Köln 2016.

38

Usp. Lothar Kreimendahl, »Die Antinomie der reinen Vernunft. 1. und 2. Abschnit«, u: Georg Mohr, Marcus Willaschek (ur.), Immanuel Kant, Kritik der reinen Vernunft, Akademie-Verlag, Berlin 1998., str. 413-446, doi: https://doi.org/10.1524/9783050050386.413. 
neposredno iskustvo slobode. ${ }^{39}$ Sloboda nije samovolja, već ona ovisi o moralnom zakonu koji prepoznajemo pomoću uma, osjećamo se odgovornima za svoja djela, te se sloboda konačno oblikuje kao postulat praktičkog uma. ${ }^{40}$

\section{Sloboda, jednakost, bratstvo}

Američka revolucija započeta 1774. predstavlja značajan moment ozbiljenja modernog razumijevanja slobode. Prvi amandman Ustava, prihvaćen 1791. godine, zabranjuje Kongresu ograničavanje slobode vjeroispovijesti, govora, tiska i okupljanja, kao i ograničavanje prava na podnošenje peticija ${ }^{41}$ Premda bi se, formalistički gledano, moglo ustanoviti da taj amandman definira tek prepreke kršenju slobode, tu se ipak ne afirmira tek sloboda od nego i sloboda $z a$, pozitivan pojam slobode, koja bi se imala sastojati u pravu na izbor svjetonazora (uključujući i slobodu religijske prakse), kao i sloboda izražavanja. Još značajniji moment predstavlja Francuska revolucija, koja je započela 1789. te je iste godine rezultirala Deklaracijom o ljudskim i građanskim pravima (Déclaration des droits de l'homme et du citoyen). Po nekim prosudbama, jedan od autora Deklaracije, markiz Lafayette, konzultirao se pri njezinoj izradi s ključnom ličnošću Američke revolucije Thomasom Jeffersonom, piscem američke Deklaracije o neovisnosti. ${ }^{42}$ Revolucija, usmjerena na ozbiljenje prosvjetiteljskih ideja i ideala slobode, ${ }^{43}$ provedena je pod sloganom Sloboda, bratstvo, jednakost (Liberté, égalité, fraternité), ${ }^{44}$ a Deklaracija predstavlja konkretizaciju ovih ideala.

$\mathrm{Na}$ granice samih proklamacija (a ne tek faktičkih ostvarenja) Francuske revolucije posebno je utjecajno ukazao Karl Marx. ${ }^{45}$ Četvrti neiskazani dio tročlanog slogana revolucije jest vlasništvo, a sâma sloboda u svojoj je biti tu zamišljena kao sloboda privatnog vlasništva. Privatno vlasništvo nad sredstvima za proizvodnju vezano je uz građansko-kapitalistički način proizvodnje, u kojemu su ljudi nužno otuđeni, već i utoliko što »čovjekov život treba privatno vlasništvo za svoje ozbiljenje « ${ }^{46}$ Otuđenje se očituje, među ostalim, i u sljedećem:

»Radnik postaje utoliko siromašniji, ukoliko proizvodi više bogatstva, ukoliko stvara više robe. Povećanjem vrijednosti svijeta stvari raste obezvređivanje čovjekova svijeta u upravnom razmjeru. Rad ne proizvodi samo robe; on proizvodi sebe sama i radnika kao robu i to u razmjeru u kojem uopće proizvodi robe [...]. Ozbiljenje rada pojavljuje se u nacionalno-ekonomskom stanju kao obestvarenje [Entwirklichung] radnika, opredmećenje kao gubitak i ropstvo predmeta, prisvajanje kao otuđenje. $\ll^{47}$

Bitno ograničenje ljudskih prava proklamiranih građanskom revolucijom sastoji se, po Marxovu mišljenju, u uspostavljanju jamstva za egoizam svojstven društvu zasnovanom na privatnom vlasništvu koje je podvrgnuto logici proizvodnje viška vrijednosti. Međutim, granice slobode u svijetu podvrgnutom toj logici nisu prirodne, tvrdi Marx, već građanski svijet u sebi sadrži potencijale vlastitog ukidanja, što vodi korjenitom širenju prostora slobode, razumljene kao ozbiljenja svih potencijala ljudskog bića u jednom svijetu s onu stranu otuđenja.

Prva asocijacija na spominjanje Marxove vizije (ili utopije, razumije se, ne u utopističkom smislu riječi $)^{48}$ razotuđenog svijeta jest komunizam. Komunizam je Marxov pojam kojim on označava taj mogući svijet, a to je svijet u kojemu je sloboda pojedinca uvjet mogućnosti slobode za sve. ${ }^{49}$ No spomenuta asocijacija ne odnosi se na taj Marxov pojam, već na poredak koji je simbolički propao rušenjem Berlinskog zida 1989. (a koji je prema danas do- 
minantnoj predrasudi predstavljao jedino moguće ozbiljenje opasne Marxove utopije, pa slijedi da sloboda ima svoje jasno omeđene granice, čije se neodgovorno prekoračivanje plaća nužnim padom u ropstvo), ${ }^{50}$ pri čemu je danas postalo posve normalno da se imenovani poredak imenuje hladonoratovskim terminom komunizam. Kakve veze mogu imati staljinistički i slični oblici autoritarno-totalitarnih režima s Marxovom idejom moglo bi se naslutiti već i iz podatka (koji se - i to tek djelomice - ne odnosi na »liberalnije« varijante prakticiranja komunističkog monopola na vlast i kontrolu cjelokupnog društva) da je jedan od ključnih pojmova Marxova mišljenja tamo proglašen ili Marxovom mladenačkom zabludom ili pak pojmom koji se odnosi isključivo na zemlje u kojima komunisti još nisu došli na vlast.

39

Usp. Rudolf Eisler, »Freiheit des Willens«, Textlog. Dostupno na: https://www.textlog. de/32302.html\# (pristupljeno 10. 6. 2019.); prema: Rudolf Eisler, Wörterbuch der philosophischen Begriffe: Historisch-quellenmässig bearbeitet, Mittler, Berlin 1904.

40

O Kantovu pojmu slobode usp. Susanne Bobzien, »Die Kategorien der Freiheit bi Kant«, Kant: Analysen, Probleme, Kritik 1 (1988), str. 193-220; Milan Kangrga, Etika ili revolucija, Nolit, Beograd 1983.; Milan Kangrga, Praksa - vrijeme - svijet: iskušavanje mišljenja revolucije, Nolit, Beograd 1984

41

Usp. George Athan Billias, American Constitutionalism Heard Round the World, 1776 1989: A Global Perspective, New York University Press, New York 2009.

\section{2}

Usp. Gregory Fremont-Barnes, Encyclopedia of the Age of Political Revolutions and New Ideologies, Greenwood, Santa Barbara 2007. str. 190.

43

Valja naglasiti da je radikalno krilo revolucionara bilo pod osobitim utjecajem Rousseauovih pogleda.

44

»Bratstvo« upućuje na pad ispod razine spomenutoga Lockeova sekulariziranja ideje jednakosti, utoliko što isključuje žene iz zajednice slobodnih. Uvid u to ograničenje proklamirane slobode svih urodio je pokretom za ravnopravnost žena s muškarcima, u kojemu je vodeću ulogu imala Olympe de Gouges, autorica Deklaracije o pravima žena i građanki (Déclaration des droits de la femme et de la citoyenne) iz 1791. godine. Usp. Hannelore Schröder, »Olympe de Gouges’ Erklärung der
Rechte der Frau und der Bürgerin«, u: Herta Nagl-Docekal (ur.), Feministische Philosophie: Ergebnisse, Probleme, Perspektiven, O1denbourg, Beč 1990., str. 202-228.

45

Usp. Mirko Jungkunz, Die Französische Revolution bei Karl Marx, GRIN Verlag, München 2004.

46

Karl Marx, Friedrich Engels, Rani radovi, prev. Stanko Bošnjak et al., Naprijed, Zagreb 1967., str. 305 .

47

Ibid., str. 245-246. Usp. Lino Veljak, »Kritika političke ekonomije kao ontologija društvenog bitka«, u: Goran Sunajko, Maroje Višić (ur.), Karl Marx, Naklada Breza, Zagreb 2018., str. 27-39.

48

O razlici između utopije i utopizma, usp Ernst Bloch, Tübinger Einleitung in die Philosophie, Suhrkamp, Frankfurt na Majni 1970., posebno str. 95; Ernst Bloch, Das Prinzip Hoffnung, Suhrkamp, Frankfurt na Majni 1959., posebno str. 98, 164-165, 285, 675.

49

Usp. Gajo Petrović, Filozofija prakse, Naprijed - Nolit, Zagreb - Beograd 1986., posebno str. 44.

50

Ovu je (u svojoj najdubljoj biti ideologijsku, da se baš ne kaže: obmanjivačku) postavku najsustavnije elaborirao jedan od rodonačelnika današnjega tzv. neoliberalizma Friedrich Hayek, a pregnantno je izražena već u samom naslovu njegova najpoznatijeg djela. Usp. Friedrich A. Hayek, Put u ropstvo, prev. Daniel Bučan, KruZak, Zagreb 2001. 


\section{Pogled na današnjicu}

Dvije su ključne dimenzije današnjih rasprava o slobodi. S jedne se strane sporovi vode o pitanju individualne slobode (u osnovi je tu riječ o drevnom problemu slobodne volje), a s druge strane o društvenim i povijesnim (zapravo: socijalno-ontologijskim) pretpostavkama slobode ljudskog bića.

Prva dimenzija problematike obilježena je antitezom između zastupnika teze po kojoj je čovjek nužno slobodan i zastupnika determinističke antiteze. Paradigmatičan slučaj teze o nužnosti ljudske slobode predstavlja Jean-Paul Sartre, posebice u svojim ranijim spisima. ${ }^{51}$ Izvanjske prepreke nisu nikakva ograničenja slobode, nego su tek ograničenja situacije, koje ljudi, zahvaljujući svojoj slobodi, mogu pokušati prekoračiti, te se na taj način sloboda potvrđuje kao ljudsko prekoračivanje danosti. Ljudi su odgovorni za to da iskoriste slobodom danu mogućnost negiranja danosti. ${ }^{52}$ Slično, Albert Camus afirmira slobodu u svijetu apsurda, gdje je moguća pobuna, koja osmišljava inače besmislen svijet. ${ }^{53}$ Poimanje ljudskog bića kao bića koje posjeduje mogućnost praktički dosežne slobode oblikovano je i u našoj filozofiji, pri čemu se posebno ističu misaoni prodori Gaje Petrovića. ${ }^{54}$

$\mathrm{Na}$ drugoj se strani oblikuje deterministička antiteza. Na tom su planu posebno utjecajni zastupnici sociobiologije. ${ }^{55}$ Sociobiologija je, po definiciji američkog evolucijskog biologa Richarda Lewontina, oblik biologijskog determinizma koji dokazuje da je organizacija ljudskog društva determinirana genskim nasljeđem evolucijske selekcije, te su stoga neizbježni dominacija muškaraca, hijerarhijsko ustrojstvo, poduzetništvo, borba za teritorij i agresivnost. ${ }^{56}$ Lewontin uvjerljivo pokazuje kako se takva sociobiologijska slika »ljudske prirode« zasniva na nizu fundamentalnih grešaka te je, stoga, ona neodrživa. Koliko god argumentacija koju nudi jedan od vodećih današnjih biologa (optužen čak i za radikalni scijentizam) ${ }^{57}$ bila znanstveno besprijekorna, nema sumnje da sociobiologijski determinizam dominira u znanstvenoj javnosti našeg vremena, pri čemu se on profilira kao zloćudna (jer je skrivena plaštem objektivnosti i znanstvenosti) ideologija usmjerena na očuvanje statusa quo i na uklanjanje svake alternative zatečenim oblicima reprodukcije života. ${ }^{58}$

A ideolozi toga status quo fundamentalno priznaju i afirmiraju, kako se čini, vrijednost samo jedne slobode: slobode ničim sputavanoga tržišta. U slobodnoj igri tržišta i konkurencije ljudska će sloboda dospjeti do svojega maksimuma, koji je ionako ograničen biologijskim determinizmom. Antiteza zasnovana na uvidu $u$ granice individualne i svake druge slobode u svijetu utemeljenom na samosvrhovitoj reprodukciji profita smjera ograničavanju slobode neljudskih moći kapitala ${ }^{59}$ u prilog oslobađanju potencijala ljudske slobode.$^{60}$ No, stvari nisu tako jednostavne: ograničavanje slobode tržišta lako i neprimjetno može prerasti i u »povijesnom nužnošću « legitimirano ograničavanje slobode ljudskih bića. Stoga, alternativa apsolutizaciji slobode kapitala niti može niti smije ležati u apsolutizaciji (tek prividno ljudske) kontrole nad proizvođenjem života ili na brkanju individualne slobode sa samovoljom. Tek se izbjegavanjem ove lažne alternative istinski može otvoriti prostor emancipacije istovjetne s oslobađanjem od svih onih ograničenja slobode koja nemaju karakter nužnosti i neumitnosti. 
51

Usp. Jean-Paul Sartre, L'être et le néant: essai d'ontologie phénoménologique, Gallimard, Pariz 1950. Usp. također i prijevod Danijela Bučana Bitak $i$ ništo, sv. I-II, Demetra, Zagreb 2006. - 2007.

\section{2}

Pitanje odgovornosti na konkretniji i životniji način postavlja Karl Jaspers. Polazeći od postavke o ljudskoj slobodi (neslobodni ne mogu biti odgovorni!), on je izravno vezuje uz pitanje o odgovornosti (pa i krivnji) za činjenje i propuštanje činjenja u historijskom kontekstu nepravde i zločina. Usp. Karl Jaspers, Pitanje krivnje, AGM, Zagreb 2006.; Michael Schefczyk, Verantwortung für historisches Unrecht, Walter de Gruyter, Berlin 2011.

\section{3}

Usp. John Foley, Albert Camus: From the Absurd to Revolt, McGill-Queen's University Press, Montreal 2008.

54

Usp. Gajo Petrović, Mogućnost čovjeka, Studentski centar Sveučilišta u Zagrebu, Zagreb

1969.; Gajo Petrović, U potrazi za slobodom, Hrvatsko filozofsko društvo, Zagreb 1990.

\section{5}

Klasičnu verziju sociobiologije formulirao je 1975. Edward O. Wilson. Usp. Richard C. Lewontin, Sociobiology: The New Synthesis, Harvard University Press, Cambridge (MA) London 2000. Usp. John Alcock, The Triumph of Sociobiology, Oxford University Press,
Oxford 2001.; Eckart Voland, Die Natur des Menschen. Grundkurs Soziobiologie, Beck, München 2007.

56

Richard C. Lewontin, »Sociobiology: another biological determinism «, Int J Health Serv. 10 (1980) 3, str. 347-363, doi: https://doi.org/10.2190/7826-DPXC-KA90-3MPR.

57

Usp. Steven Pinker, The Blank Slate: The Modern Denial of Human Nature, Penguin, New York 2002., str. 149.

58

Takvu znanstveno legitimiranu ideologiju koju srećemo u sociobiologiji dodatno potkrjepljuju brojna interdisciplinarna neuroznanstvena istraživanja koja se temelje na sociobiologijskoj paradigmi. Usp. Patricia S. Churchland, Braintrust: What Neuroscience Tell Us about Morality?, Princeton University Press, Princeton 2011.

59

Preciznije: ljudski proizvedenih, ali od ljudi otuđenih te utoliko i neljudskih moći.

60

O nekim važnim aspektima tih granica slobode $\mathrm{u}$ dominantnom poretku usp. npr. - danas već klasično - djelo Herberta Marcusea Čovjek jedne dimenzije. Rasprave o ideologiji razvijenog industrijskog društva, prev. Branka Brujić, Svjetlost, Sarajevo 1989. 


\title{
Lino Veljak
}

\section{On the History of the Notion of Freedom}

\begin{abstract}
The notion of freedom ( $g k$. eleuthería, lat. libertas) was in ancient philosophy formed in the sense of the privileges belonging to adult free citizens, and thus foreigners, minors, women, and slaves were deprived of the possibility of freedom. This definition of freedom was also adopted by Roman law, unlike Stoic philosophy and the New Testament Christianity, where freedom was extended to belong to all human beings. In comparison, the Stoics (at least partially) condemn slavery, while Christianity eschatologises freedom (all people are free as God's children, but this does not imply the abolition of slavery in this world). The Middle Ages built on such a concept of freedom. Still, in that period the secular concept of freedom was formulated, which especially comes to the fore in the Magna charta libertatum. The modern concept of freedom was shaped in the Modern Age, from Locke's definition of life, freedom, and property as inalienable civil rights, through Voltaire's request for the freedom of thought and Rousseau's identification of freedom with the essence of human being, to Kant's understanding of freedom that is possible only through the mind. The ideals of French Revolution, Liberty, Equality, Fraternity (liberté, égalité, fraternité), are concretised in the Declaration of the Rights of Man and of the Citizen (and Marx points at the limits of freedom established by this declaration). John Stuart Mill formulated the classical liberal concept of freedom. Today freedom is discussed, on the one hand, at the level of questions about individual freedom (for example, according to Sartre and Camus, the human being is necessarily free, while according to some representatives of sociobiology and researchers in the field of neurobiology, the human being is essentially genetically determined), and on the other hand, at the level of the problematisation of social presumptions regarding the freedom of human being (where the question of whether private property is the condition of the possibility of freedom or an obstacle to real freedom lies at the centre of discussion).
\end{abstract}

\section{Keywords}

freedom, eschatology, secularity, civil rights, human rights, mind, equality, fraternity, liberality, ownership 